See discussions, stats, and author profiles for this publication at: https://www.researchgate.net/publication/233149351

\title{
Determination of apparent and composite friction factors for flooded equatorial natural rivers
}

Article in International Journal of River Basin Management · March 2008

DOI: 10.1080/15715124.2008.9635332

CITATIONS

5 authors, including:

Sai Hin Lai

University of Malaya

111 PUBLICATIONS 535 CITATIONS

SEE PROFILE

Puong Ling Law

University Malaysia Sarawak

38 PUBLICATIONS 340 CITATIONS

SEE PROFILE

Some of the authors of this publication are also working on these related projects:

Water Sensitive Urban Design View project

CFD and Experimental Modelling of Flow Pattern and Hydraulic Characteristics through Modular Channels View project
178

Saad Dahlab University

29 PUBLICATIONS 143 CITATIONS

SEE PROFILE

Aminuddin Ab Ghani

Universiti Sains Malaysia

225 PUBlications 2,437 CITATIONS

SEE PROFILE 


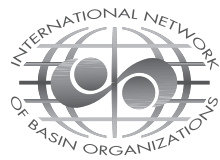

Intl. J. River Basin Management Vol. 6, No. 1 (2008), pp. 3-12

(C) 2008 IAHR, INBO \& IAHS

\section{Determination of apparent and composite friction factors for flooded equatorial natural rivers}

LAI SAI HIN, Lecturer, River Engineering and Urban Drainage Research Centre (REDAC), Universiti Sains Malaysia, Engineering Campus, 14300 Nibong Tebal, Penang, Malaysia.E-mail: redaclai@eng.usm.my

NABIL BESSAIH, Department of Civil Engineering, Faculty of Engineering, Universiti Malaysia Sarawak (UNIMAS), 94300 Kota Samarahan, Sarawak, Malaysia

LAW PUONG LING, Department of Civil Engineering, Faculty of Engineering, UNIMAS, 94300 Kota Samarahan, Sarawak, Malaysia

AMINUDDIN AB. GHANI, Professor and Deputy Director, REDAC, Universiti Sains Malaysia, Engineering Campus, 14300 Nibong Tebal, Penang, Malaysia.E-mail: redac02@eng.usm.my

MAH YAU SENG, Department of Civil Engineering, Faculty of Engineering, UNIMAS,

94300 Kota Samarahan, Sarawak, Malaysia

\section{ABSTRACT}

This paper presents results, calculated from field measurements taken in several frequently flooded natural rivers, which include D and R relationships, variation of flow resistance with depth of flow, the apparent friction factor, and the composite friction factor for flooded natural rivers. The results obtained have shown the complexity of flow resistance in natural rivers due to the interaction between the main channel and floodplain flow. The interaction has given rise to a pair of apparent shear stresses at the interface region, which can significantly reduce the discharge capacity of the rivers. The apparent shear was quantified in terms of an apparent friction factor, $f_{a}$, and it was found that the apparent shear stress is many times greater than the averaged boundary shear stress of the rivers. Based on the averaged boundary shear stress and apparent shear stress, the composite (actual) friction factor for the rivers can be estimated accurately $\left(R^{2}=0.99\right)$ using a statistical method that had been derived.

Keywords: Flow resistance; friction factor; momentum transfer; natural river; overbank flow.

\section{Introduction}

The estimation of resistant coefficient and hence discharge capacity in a channel or river is one of the fundamental problems facing the river engineers. Without an accurate estimate of conveyance, very little confidence can be placed in the subsequent design calculations or predictions.

At the present moment, the accuracy of the friction factor for predicting flow characteristics in a particular reach, with a dynamic vegetation and flow regime remains questionable. Many studies of flow resistance have been carried out to provide an accurate estimate of resistance coefficient in any given circumstance especially under overbank conditions. However, none as yet has lead to a general applicable method. In addition, as most of this work is based on laboratory experiments, these results may not reflect the real situations in natural rivers with highly irregular shape and variations in surface roughness. In the work presented, an attempt was made to focus on the estimation of flow resistance in natural rivers under flood conditions.

\section{Reviews}

An important component in open channel flow is the estimation of flow resistance resulting from the viscous and pressure drag over the wetted perimeter. Such resistance is commonly represented by parameters such as Manning's roughness coefficient $(n)$, or the Darcy-Weisbach friction factor $(f)$, as given below.

The Manning equation gives

$$
n=\left(R^{2 / 3} S_{o}^{1 / 2}\right) / V
$$

The Darcy-Weisbach equation for channel flow gives

$$
f=\left(2 g D S_{o}\right) / V^{2}
$$

Received on February 17, 2007. Accepted on April 21, 2007. 